Review Article

\title{
Genetic Diversity of Groundnut Rosette Disease Causal Agents Towards Its Management: A Review
}

\author{
Benard Mukoye*, Anthony Simiyu Mabele \\ Department of Biological Sciences, School of Natural Sciences (SONAS), Masinde Muliro University of Science and Technology (MMUST), \\ Kakamega, Kenya
}

Email address:

Btemukoye@gmail.com (B. Mukoye), mabeleanthony@gmail.com (A. S. Mabele)

*Corresponding author

\section{To cite this article:}

Benard Mukoye, Anthony Simiyu Mabele. Genetic Diversity of Groundnut Rosette Disease Causal Agents Towards Its Management: A Review. International Journal of Genetics and Genomics. Vol. 7, No. 1, 2019, pp. 12-17. doi: 10.11648/j.ijgg.20190701.12

Received: March 7, 2019; Accepted: April 16, 2019; Published: June 3, 2019

\begin{abstract}
In this review, the genetic diversity of the three causal agents of Groundnut Rosette Disease (GRD) in Sub-Saharan Africa (SSA) are discussed. Epidemics of GRD viruses in SSA, often reduce groundnut productivity. The etiology of GRD is a complex, involving three agents; Groundnut rosette assistor luteovirus (GRAV), Groundnut rosette umbravirus (GRV) and a Satellite-RNA (Sat-RNA) of GRV. The complex etiology and lack of sensitive and specific diagnostic tools, are major limitations in understanding the epidemiology of GRD viruses, and developing appropriate management strategies for the disease. Nucleotide identity of 97 to 100\% among GRAV isolates from different regions in Kenya have been reported. Sat-RNA sequences from Kenya shared nucleotide identity of 95\% with Malawian isolate (M24S) and 89\% with Nigerian isolate (NG3a). GRAV CP gene was highly conserved (97-99\%) regardless of the geographical distance. However, for GRV and Sat-RNA diversity increased with increase in geographical distance. In addition, phylogenetic analysis showed that isolates of GRV (ORF3 and 4) and Sat-RNA clustered together depending on the country of origin. Recent study has unveiled a chlorotic variant of Sat-RNA in Kenya with $97 \%$ sequence identity to the Malawian chlorotic isolate (M24S). Pathogen derived resistance (PDR) suitable for each diverse regions where the disease occurs is a promising management strategy which mainly depends in studies to deeply understand the genetic diversity of the three GRD causal agents. Currently, GRAV-CP is the best candidate for PDR.
\end{abstract}

Keywords: Arachis hypogaea, GRAV, GRV, Sat-RNA, Sequence Diversity

\section{Introduction}

Groundnut rosette disease (GRD) was first reported in 1907 from Tanganyika, now called Tanzania [1]. Since then, GRD has been reported in several other Sub-Saharan African Countries, which include: Angola, Burkina Faso, Cote d'lvoire, Gambia, Ghana, Kenya, Madagascar, Malawi, Niger, Nigeria, Senegal, South Africa, Swaziland, Uganda and the Democratic Republic of Congo (DRC) [2-4]. The virus agents of GRD have not been detected elsewhere in the world, except in SSA, despite the fact that groundnut is grown in more than 100 countries around the world, and the vector aphid, Aphis craccivora Koch, is found in almost all the groundnut growing regions in the world.

Symptoms similar to GRD, have been reported in some countries of Asia and South America, but diagnostic tests, to confirm the presence of the disease, have not been conducted [5]. This disease is considered to be endemic to groundnut growing countries of SSA, and its offshore islands of Madagascar. Since GRD is limited to SSA, it is likely that groundnut introduced from South America, sometime during the sixteenth century by the Portuguese, was infected by a pathogen endemic to SSA, and is therefore an example of a new encounter phenomenon [6]. The new encounter phenomenon occurs, when a crop has been introduced into a new geographical region, and pests or pathogens that evolved with other host species, attack the newly introduced crop [7]. Distinct chlorotic, green and mosaic rosette symptoms caused by synergism among groundnut rosette assistor luteovirus (GRAV), groundnut rosette umbravirus (GRV) and its satellite 
RNA (sat-RNA), makes it a unique and fascinating virus disease whose origin and perpetuation in nature still remains inconclusive in spite of substantial advance in knowledge.

Epidemics of GRD viruses in SSA, often reduce groundnut production, and cripples rural economy. Although not present every year, epidemics occur with devastating losses. In 1975, GRD affected 0.7 million ha of groundnut in Northern Nigeria and caused an estimated yield loss of 0.5 million tonnes, valued at US\$ 5 million [6]. In 1995-1996, Eastern Zambia lost 43,000 ha of groundnut to GRD viruses estimated at US\$ 5 million. In 1994-1995, farmers in central Malawi abandoned the crop by $23 \%$, following an unpredictable epidemic, whose annual loss was estimated at US\$ 155 million $[8,9]$.

The complex etiology and lack of sensitive and specific diagnostic tools, are major limitations in understanding the epidemiology of GRD viruses, and developing appropriate management strategies for the disease. To date, lack of sufficient research on the occurrence, distribution and sequence diversity of GRD causal agents [2 - 4], has resulted in continued and increased yield losses amongst groundnut farmers. Recent observations made in groundnut farms in western Kenya have shown that GRD is very severe and highly variable in symptoms diversity causing upto $100 \%$ yield losses [10]. The cause of this could lie in the genetic variability of GRD causal agents, specifically the Sat-RNA of GRV [11]. Reports of groundnut crop damage by GRD, underscores the need for further epidemiological studies, and appropriate control/management strategies that reduces the inoculum sources for viral diseases, to prevent resistant/tolerant varieties from succumbing to GRD at high inoculum pressure [12].

\section{Etiology and Genome Organizations of GRD Agents}

The etiology of GRD is a complex, involving synergistic interaction of the three causal agents; Groundnut rosette assistor virus (GRAV), Groundnut rosette umbravirus (GRV) and a satellite-RNA (Sat-RNA) of GRV [13]. These three components are intricately dependent on each other, and all three play a crucial role in the biology and perpetuation of rosette disease which is not one but three diseases: chlorotic rosette, green rosette and mosaic rosette. Groundnut rosette virus (GRV) needs assistor GRAV for mechanical transmission by the aphid, Aphis craccivora. The virus-like nucleic acid molecule, Satellite-RNA, occurs in different forms, and results in at least three types of distinct field symptoms, chlorotic (yellowing), green and mosaic rosette [14]. No virus-like particles have been reported for GRV, but infected plants yield infective ssRNA. Infected leaves also contain dsRNA, with prominent electrophoretic species of 4.6kbp (dsRNA-1) and $1.3 \mathrm{kbp}$ (dsRNA-2), a very abundant species of $900 \mathrm{bp}$ (dsRNA-3), and numerous minor species of intermediate mobility. The GRV sat-RNAs associated with chlorotic and green rosette disease, in different regions of
Africa, are 895-903 nucleotides long, and are at least $87 \%$ identical. The sat-RNA contains upto five open reading frames (ORFs), in either positive or negative sense, but the role of any proteins expressed from these ORFs is unknown. The intricate interaction between GRAV, GRV and sat-RNA is crucial to the development of the disease. GRV, a member of the genus Umbravirus, has a single-stranded, positive-sense RNA genome of 4,019 nt that contains four large open reading frames (ORFs). ORF 2 is a putative RNA-dependent RNA polymerase and is likely expressed as a fusion protein with the product of ORF1 by a -1 frameshift mechanism [13]. The $3^{\prime}$ ORFs $(3,4)$ are almost completely overlapping. The protein encoded by ORF 3 was shown to be a trans-acting long-distance movement protein that can traffic nonrelated viral RNA systemically, while analysis of the ORF 4 putative amino acid sequence suggests that it may be involved in cell-to-cell movement

Groundnut rosette assistor virus (GRAV) is a member of the genus Luteovirus and family Luteoviridae [7]. GRAV virions are non-enveloped, isometric shaped with $28 \mathrm{~nm}$ diameter particles of polyhedral symmetry. Their genome is a non-segmented, single molecule of linear positive sense, single-stranded RNA of ca.6900 nucleotides, which encodes for structural and non-structural proteins [15]. Like other members of the luteovirus, GRAV is thought to encode for six ORFs. Only the coat protein $(\mathrm{CP})$ region of GRAV genome is sequenced (Gene Bank Accession \# z 68894 af195502, af195825). Virions are made of single CP subunits of size $24.5 \mathrm{kDa}$, and the virus is antigenetically related to Bean/pea leaf roll virus, Beet western yellow virus and Potato leaf roll virus [16]. Groundnut rosette assistor virus (GRAV) is transmitted by Aphis craccivora, in a persistent circulative manner, and experimentally by grafting, but not by mechanical sap inoculation, seed, and pollen or by contact between the plants. GRAV acts as a helper virus for aphid transmission of GRV and sat-RNA. Unlike sat-RNA and GRV, GRAV is phloem limited and the virus replicates autonomously, in the cytoplasm of the phloem tissue [15]. Groundnut (Arachis hypogaea) is the only known natural host of GRAV. The virus is reported to occur wherever GRD has been reported. The GRAV on its own causes symptomless infection or transient mottle, and can cause significant yield loss in susceptible groundnut cultivars by reducing total dry mass of the plant and seed weight [17]. GRAV, GRV and sat-RNA are dependent on each other, and all the three agents play a crucial role in the biology and perpetuation of the disease. GRV RNA and sat-RNA are packaged in the CP of GRAV to form virus particles that can be transmitted by aphids. The sat-RNA depends on GRV for replication while GRV depends on sat-RNA for aphid transmission [9] and [13]. The sat-RNA is necessary for encapsidation of GRV of GRV RNA into the coat protein of GRAV [18]. GRAV and GRV contribute little to disease symptoms in groundnut apart from yield loss [9].

Groundnut rosette virus (GRV) belongs to the genus Umbravirus and family Tombusviridae [1]. On isolation and characterization, the virus has no structural coat protein [13], 
and thus forms no conventional virus particles. [13] detected enveloped bullet-shaped structures in the ultra-thin sections due to GRV infection as opposed to real virions. The virus genome is a non-segmented, single linear molecule of single-stranded, positive sense RNA of size ca.4019 nucleotides, which encodes for four ORFs [13]. The genome of GRV isolate when completely sequenced (Gene Bank Accession \#z66910), and several partial sequences are available in the Gene bank. The GRV replicates autonomously in the cytoplasm of the infected tissues [13]. Groundnut rosette virus (GRV) on its own causes transient symptoms, but a Sat-RNA associated with GRV is responsible for rosette disease symptoms [1]. GRV depends on GRAV for encapsidation of its RNA, and transmission by Aphis craccivora in a persistent mode [19]. The virus is transmitted by grafting and mechanical inoculation but not through seed, pollen or by contact between the plants [1]. Groundnut is the only known natural host, but several experimental hosts in the families Chenopodiaceae and Solanaceae have been reported [1]. No strains of GRV have been reported, and the virus is restricted to SSA and its offshore islands of Madagascar [20].

The Satellite-RNA, subviral RNAs of GRV, belongs to the sub-group-2 (small linear) satellite-RNAs. It is a single-stranded, linear non-segmented RNA of 895 to 903 nucleotides [21]. It totally depends on GRV for its replication, encapsidation and movement, both within and between the plants. The Sat-RNA variants are responsible for rosette symptoms, and plays a critical role in GRAV helper virus dependent transmission of GRV [22]. Different variants of Sat-RNA have been shown to be responsible for different rosette symptoms, in other indicator plants which acts as alternative hosts for GRD inoculum [11]. The Sat-RNA has up to five ORFs in positive or negative sense but no protein products have been isolated [21]. It is mechanically transmissible along with GRV, and is also transmitted by aphids, in the presence of GRV and GRAV [1]. The sequences of 10 variants of GRV Sat-RNA have been determined [21].

\section{Symptoms of GRD}

Variability in Sat-RNA is mainly responsible for symptom variations [22]. In addition, differences in genotypes, plant stage infection, variable climatic conditions and mixed infections with other viruses, contributes to symptom variability under field conditions [17, 23]. In Eastern Uganda, GRD viruses resulting in green rosette symptoms predominate [24]. This is in contrast with [2], who reported that chlorotic rosette symptoms of GRD have been the predominant form throughout SSA and western Kenya. This finding is of utmost importance because, Eastern Uganda and partly neighbouring western Kenya is a major groundnut grower in SSA. The dynamics of the GRD virus symptomatology, needs further research [24]. RNA viruses exist as "quasispecies" [25] in the infected plants, and thus the population complexity of GRAV, GRV and Sat-RNA in the field has the potential to be large. The potential permutations among variants of the three causal agents, are able to form viable alternatives and their capacity to adapt to diverse and changing econiches, are thus enormous. With time, this continuous "evolution" of GRD viruses, under strong selection pressure, can lead to new disease patterns. For instance in Nigeria, a clear shift occurred from green to chlorotic rosette, over a period of about 20 years. The shift could be due to changes, in the genome sequences of GRD agents, or to different vector biotypes and cropping patterns [24].

Rosette disease manifest in two major symptoms; chlorotic (yellow) and green rosette which occur throughout the SSA, and sometimes occur in the same field [26]. A less common third symptom variant, called mosaic rosette, resulting from mixed infection of the groundnut cultivars by the Sat-RNA causing chlorotic and green mottled variant, has been reported from East Africa [16, 1]. Mosaic rosette is of low incidence but of wide occurrence in Southern Africa and East Africa [10] (Figure 1).
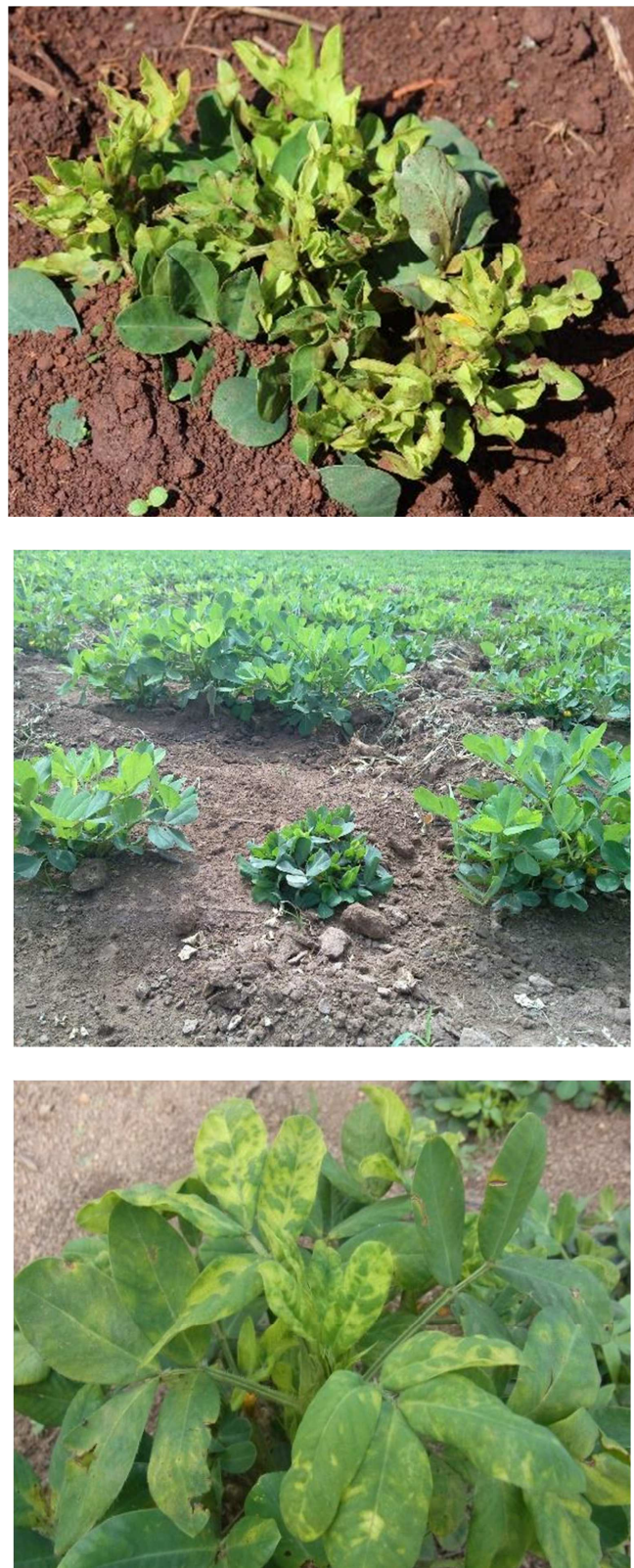


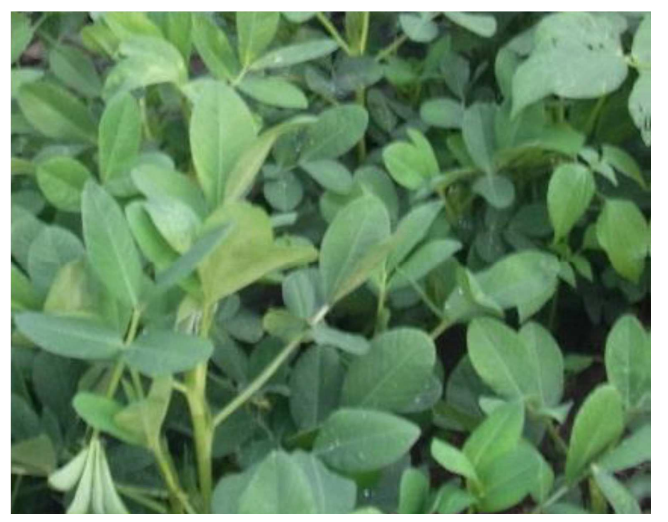

Figure 1. Common GRD symptoms, from top left clockwise; yellow rosette, green rosette [27], mosaic rosette and healthy groundnut [10].

\section{Genetic Diversity of GRD Agents}

The genetic diversity of the GRD causal agents in Ghana, Nigeria, Malawi and Kenya has been determined. The diversity of GRAV in the Kenyan isolates from different regions has been determined using the $\mathrm{CP}$ gene sequence. Nucleotide identity of 97 to $100 \%$ among GRAV isolates from different regions in Kenya were observed. These isolates displayed 96 to $98 \%$ nucleotide identity when compared with those from Malawi and Nigeria [2]. In the same study, [2], reported the nucleotide sequences of GRV ORF3 and 4 showed $99 \%$ nucleotide identity among the Kenyan isolates which when compared with Malawian and Nigerian isolates, showed sequence homology of 95 to $96 \%$ with the Malawian isolates and $87 \%$ to $88 \%$ with the Nigerian isolates. Sat-RNA sequences from Kenya shared nucleotide identity of $95 \%$ with Malawian isolate (M24S) and $89 \%$ with Nigerian isolate (NG3a). [7], observed that the GRAV CP gene was highly conserved (97-99\%) regardless of the geographical distance. Recent study has unveiled a chlorotic variant of Sat-RNA in Kenya with $97 \%$ sequence identity to the Malawian chlorotic isolate (M24S). This variant only clustered with yellow blotch and chlorotic variants of Sat-RNA. In addition, the GRAV CP gene showed the similar diversity to the one described earlier (Manuscript under preparation).

\section{Biotechnological Approaches in Management of GRD}

Pathogen-derived resistance (PDR) [28] provides a good strategy for controlling GRD through the generation of transgenic groundnut. This could potentially be achieved by introducing GRAV or GRV genomic sequences or genes, or Sat-RNA-derived sequences that down regulate GRV replication, into suitable groundnut cultivars. However, the success of PDR-, RNA- or protein-mediated [28] resistance, is highly influenced by the degree of sequence homology between the sequence of the transgene and the challenging virus [29].

An earlier effort to develop PDR, the degree of genetic variability within the three GRD agents from two diverse groundnut-growing regions of SSA (Malawi and Nigeria) was examined by [7] with the hypothesis that this type of resistance could be introduced by deducing the most conserved region in the GRD agents from different regions of SSA. The CP of GRAV is suggested to be the most probable candidate for developing PDR for GRD across SSA, because it appeared to be the most highly conserved between the two distinct regions [7].

The lack of information on the distribution of the disease and viral isolate variation hampers the management, and development of control measures aimed at reducing losses [30]. Since GRD epidemics occur without warning, an in depth study of the variability in the three components of groundnut rosette should be thoroughly investigated. Identification of specific component of resistance in the rosette resistant germplasm and breeding lines by testing for GRAV, GRV and Sat-RNA in different agro-climatic zones of Africa should be embarked upon as a matter of urgency. Identification of the dry season hosts of the aphid vector and the three components of the rosette disease should be initiated in all African sub-regions. The behaviour of vector biotypes collected from different agro-ecological zones, and their transmission efficiency of chlorotic, green and mosaic form of rosette on a range of groundnut genotypes, including the rosette resistant/tolerant genotypes and dry season hosts, needs to be thoroughly investigated. The resistance when found should be incorporated into germplasm that have desirable characteristic including early maturation. All causal agents of GRD are persistently transmitted by Aphis craccivora Koch and so far there is no evidence of seed transmission [18]. Deployment of host resistance/tolerance is the most cost-effective way to manage epidemics that come without warning, given that groundnuts are produced by subsistent smallholder farmers. Breeding of resistant genotypes and their deployment is most effective when supported by efficient pathogen diagnostic systems, even in the absence of symptoms. To overcome the inherent disadvantage of diagnostic cost as well as to improve diagnostic capacity, Next Generation Sequencing (NGS) technologies, multiplex PCR and RT-PCR variants in which more than one target sequence is amplified using more than one pair of primers, is an interesting alternative to support screening for individual or multiple GRD viruses and disease pathological studies [31,32].

\section{Perspectives and Status of GRD in SSA}

Limited information is available on the genetic diversity of GRD causal agents in SSA, making it a unique and fascinating virus disease whose origin and perpetuation in nature still remains inconclusive, in spite of substantial advance in knowledge. The variability of field isolates of the three causal agents of GRD has been ascertained in Malawi, Nigeria [7] and Kenya [2], but distinct host range variability and distribution of GRD inoculum on alternative host plants has not been reported in SSA environments that interact negatively with specific genotypes of groundnut cultivars. 
Reports of groundnut crop damage by GRD, underscores the need for further epidemiological studies, and appropriate control/management strategies that reduces the inoculum sources for viral diseases, to prevent resistant/tolerant varieties from succumbing to GRD at high inoculum pressure ([12]. Only groundnuts have been found naturally infected with the GRD viruses or the satellite RNA, although other crop plants can be infected experimentally. As the viruses are not seed-borne, it may mean that volunteer (self-seeded) groundnuts are the source of infection, which is carried to crops by winged aphids. Where volunteer groundnuts do not survive the dry season, aphids on the wind may bring the viruses from other parts of the continent.

Cropping practices have led to effective management practices for controlling GRD, however, the approach is seldom feasible for the subsistence farming systems of SSA. In the case of host-plant resistance, the resistance that is available is against GRV and can be overcome under high inoculum pressure [29]. Resistance is not yet available in different genetic backgrounds of groundnut suitable for the diverse seasons and farming systems of SSA. No resistance has yet been reported against GRAV. Pathogen-derived resistance (PDR) [7] represents an alternate strategy for controlling GRD through the generation of transgenic groundnut.

\section{Conclusion}

All the three GRD agents, GRAV, GRV and the Sat-RNA, which are intricately dependent on each other in GRD etiology show varied degrees of variability at genetic level. This depends on largely on geographical distance of isolates. However GRAV CP gene seemed to be more conserved displaying very little diversity regardless of geographical distance. The disease is still a challenge as no single management strategy has been developed. Pathogen derived resistance (PDR) suitable for each diverse regions where the disease occurs is a promising management strategy which mainly depends in studies to deeply understand the genetic diversity of the three GRD causal agents. The GRAV CP gene seems to be the most conserved across SSA and therefore a suitable candidate for PDR.

\section{References}

[1] Waliyar, F., Kumar, P. L., Ntare, B. R., Monyo, E., Nigam, S. N., Reddy, A. S., Osiru, M. \& Diallo, A. T. 2007. A Century of Research on Groundnut Rosette Disease and its Management . Information Bulletin no. 75. Patancheru 502 324, Andhra Pradesh, India. International Crops Research Institute for the Semi-Arid Tropics, pp 40. ISBN: 978-92-9066-501-4.

[2] Wangai, A. W., Pappu, S. S., Pappu, H. R., Okoko, N., Deom, C. M. \& Naidu, R. A. 2001. Distribution and characteristics of groundnut rosette disease in Kenya. Plant Disease. 85 (5): 470-474.

[3] Kidula, N., Okoko, N., Bravo-Ureta, B. E., Thuo, M. \& Wasilwa, L. 2010. A preliminary analysis of yield differences in groundnuts between research and non-research farmers in Kenya. In paper presented at the $12^{\text {th }}$ KARI biennial scientific conference, 8-12 November 2010, Naiobi Kenya.

[4] Thuo, M., Bell, A. A., Bravo-Ureta, B. E., Lachaud, M. A., Okello, D. K., Okoko, N. E., Kidula, N. L., Deom, C. M. and Puppala, N. 2014. Effects of social network factors on information acquisition and adoption of improved groundnut vaarieties: the case of Uganda and Kenya. Agric. Hum. Values, 31: 339-353.

[5] Reddy, D. V. R. 1991. Groundnut viruses and virus diseases; Distribution, identification and control. Rev. Plant Pathol. 70: 665-678.

[6] Olorunju, P. E. \& Ntare, B. R. 2001. Combatting viruses and virus diseases of groundnut through the use of resistant varieties. A case study of Nigeria.

[7] Deom, C. M., Naidu, R. A., Chiyembekeza, A. J., Ntare, B. R. $\&$ Subrahmanyam, P. 2000. Sequence diversity with the three agents of groundnut rosette disease. Phytopathol. 90: 214-219.

[8] SADC/ICRISAT Groundnut Project Annual Progress Report for 1996. Chitedze Research Station, PPO Box1096, Lilongwe, Malawi.

[9] Taliansky, M. E., Robinson, D. J. \& Murant, A. F. 2000. Groundnut rosette disease virus complex: Biology and Molecular Biology. Advances in virus research. 55: 357-400.

[10] Mabele, A. S., Were, H. K., Ndong'a, M. F. O., Mukoye, B. \& Torrance, L. 2018. Occurrence, distribution and diversity of groundnut rosette assistor virus (GRAV) causing groundnut rosette disease (GRD) in western Kenya. In: KIBU International Conference (2018). Creativity and Innovation for Sustainable Development. Book of Abstracts of Kibabii University 3rd International Conference 12-14 June 2018. Kibabii University, Bungoma Kenya. ISBN:978-9966-59-011-5. pp 16/35

[11] Murant, A. F., \& Kumar, I. K. 1990. Different variants of the satellite RNA of groundnuts rosette virus are responsible for the chlorotic and green forms of groundnut rosette disease. Ann. Appl. Biol. 117: 85-92.

[12] Appiah, A. S., Offei, S. K., Tegg, R. S., \& Wilson, C. R. 2016. Varietal response to groundnut rosette disease and the first report of Groundnut ringspot virus in Ghana. Plant Dis. 100 (5): 946-952.

[13] Taliansky, M. E. \& Robinson, D. J. 2003. Molecular Biology of umbraviruses: Phantom warriors. J. Gen. Virol. 84: 1951-1960.

[14] Kayondo, S. I., Rubaihayo, P. R., Ntare, B. R., Gibson, P. I., Edema, R., Ozimati, A. \& Okello, D. K. 2014. Genetics of resistance to groundnut rosette virus disease: African crop science journal, 22:21-29. ISSN:1021-9730/2014.

[15] Murant, A. F., Rajeshwari, R., Robinson, D. J., and Raschke, J. H. 1988. A satellite RNA of groundnut rosette virus that is largely responsible for symptoms of groundnut rosette disease. J. Gen. Virol. 69:1479-1486.

[16] Scott, K. P., Farmer, M. J., Robinson, D. J., Torrence, L. \& Murant, A. F. 1996. Comparison of the coat protein of groundnut rosette assistor virus with those of other luteovirus. Ann. Appl. Biol. 128: 77-83. 
[17] Naidu, R. A \& Kimmins, F. M. 2007. The effect of groundnut rosette assistor virus on the agronomic performance of four groundnut (Arachis hypogaea L.) genotypes. J. Phytopathol. 155:350-356.

[18] Murant, A. F. (1990). Dependence of groundnut rosette virus on the satellite RNA as well as groundnut rosette assistor luteovirus for transmission by Aphis craccivora. Journal of General Virology 71: 2163-2166.

[19] Robinson, D. J., Ryabov, E. V., Raj, S. K., Roberts, I. M. \& Taliansky, M. E. 1999. Satellite RNA is essential for encapsidation of groundnut rosette umbravirus RNA by groundnut rosette assistor luteovirus coat protein. Virol. 254: 104-114.

[20] Okello, D. K., Monyo, E., Deom, C. M., Ininda, J. \& Oloka, H. K. 2013. Groundnuts production guide for Uganda: Recommended practices for farmers. National Agricultural Research Organization, Entebbe. ISSN: 978-9970-401-06-2

[21] Blok, V. C., Ziegler, A., Robinson, D. J. \& Murant, A. F. 1994. Sequences of 10 variants of the satelitte- like RNA -3 of groundnut rosette virus. Virology. 202: 25-32.

[22] Taliansky, M. E. \& Robinson, D. J. 1997. Trans-acting untranslated elements of groundnut rosette virus satelitte RNA are involved in symptom production. J. Gen. Virol. 78: $1277-1285$

[23] Naidu R. A, Kimmins F. M, Deom C. M, Subrahmanyam P, Chiyembekeza AJ, van der Merwe PJA. 1999a. Groundnut rosette: a virus disease affecting groundnut production in sub-Saharan Africa. Plant Dis 83: 700-709.

[24] Okello, D. V, Akello, L. B, Tukamuhabwa, P., Odongo, T. L, Ochwo-Ssemakula, M., Adriko, J. \& Deom, C. M. 2014. Groundnut rosette disease symptom types, distribution and management of the disease in Uganda. African journal of plant science. 8 (3): 153-163.

[25] Roossinck, M. J. 1997. Mechanism of plant virus evolution. Ann. Rev. Phytopathol. 35: 191-209.
[26] Mugisa, I. O., Karungi, J., Akello, B., Ochwo-Ssemakula, M. K N., Biruma, M., Okello, D. K. \& Otim, G. 2016. Determinants of groundnut rosette virus disease occurrence in Uganda. Elsevier crop protection journal. 10: 10-19.

[27] Okello, D. K., Ugen, M. A., Tukamuhabwa, P., Ochwo-Ssemakula, M., Odong, T. L., Adriko, J., Kiconco, F., Male, A. and Deom, C. M. 2017. Molecular diagnostics of groundnut rosette disease agents in Uganda: Implications on epidemiology and management of groundnut rosette disease. Journal of plant breeding and crop science. 9 (5): 63-70.

[28] Deom, C. M. 1999. Engineered resistance. Pages 1307-1314 in: Encyclopedia of Virology, 2nd ed. A. Granoff and R. Webster, eds. Academic Press, London.

[29] Usman, A., Danquah, E. Y., Ofori, K. \& Offei, S. K. 2013. Genetic analysis of resistance to rosette disease of groundnut (Arachis hypogaea L.). A thesis submitted to the University of Ghana, Legon. ISSN: 10293978.

[30] Appiah, A. S., Sossah, L. F., Tegg, S. R., Offei, K. S. \& Wilson, R. C. 2017. Assessing sequence diversity of goundnut rosette disease agents and the distribution of groundnut rosette assistor virus in major groundnut-producing regions of Ghana. Trop. Plant Pathol.10: 07-14.

[31] Anitha, S., Monyo, E. S. \& Okori, P. 2014. Simultaneous detection of groundnut rosette assistor virus (GRAV), groundnut rosette virus (GRV) and satellite RNA (satRNA) in groundnuts using multiplex RT-PCR. Arc. virol.159:3059-3062, doi: 10.1007/s00705-014-2139-7.

[32] Mukoye B., Mangeni B. C., Ndong'a M. F. O. and Were H. K. 2018. Next generation sequencing as a tool in modern pest diagnosis. A case study of groundnuts (Arachis hypogaea) as a potential host of new viruses in Western Kenya. $2^{\text {nd }}$ Phytosanitary conference $4^{\text {th }}-8^{\text {th }}$ June, 2018. Kenya Plant Health Inspectorate Service (KEPHIS), Nairobi, Kenya. 